\section{Dydaktyka historii sztuki na UKSW - refleksje praktyka dotyczące metodyki kształcenia}

\section{WSTĘP}

Dydaktyka historii sztuki w Instytucie Historii Sztuki Uniwersytetu Kardynała Stefana Wyszyńskiego nie jest przedmiotem teoretycznych rozważań, lecz kształcenia od 2001 r. Potrzebę wprowadzenia zajęć tego typu zdeterminowała chęc włączenia w program studiów z historii sztuki elementów praktycznych, które będą przed studentami otwierały nowe możliwości na rynku pracy.

Historia sztuki od początku istnien szkól artystycznych w Polsce, a pierwsze z nich powstawały już w 1945 r., była przedmiotem nauczania w szkołach plastycznych. Stopniowo też została wprowadzona, jako element innowacji pedagogicznej i eksperymentu, do niektórych szkół ogólnokształcących, także podstawowych, a póź niej gimnazjów. Mimo że pierwotnie wiązała się z kształceniem elitarnym w wyniku reformy szkolnictwa i wprowadzania egzaminów zewnętrznych stata się d zaminie maturalnym¹. Od $2012 \mathrm{r}$. jest też

Podstawa prawna pierwszego egzaminu maturalnego z historii sztuki była Ustawa o systemie oświaty
z 1991 r., Dziennik Ustaw z 1991 r.,nr 95 poz 425 dwa rozporządzenia: Rozporzaddzenie Ministra Eduka

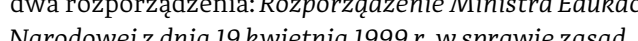

nauczana w liceach ogólnokształcących jako przedmiot na poziomie rozszerzonym, do wyboru przez uczniów, w liczbie ośmiu godzin w cyklu kształcenia. Dlatego bardzo ważne jest, aby przyszli nauczyciele historii sztuki mieli odpowiednie kwalifikacje, któMinistra Edukacji Narodowej oraz Ministra Kultury i Dziedzictwa Narodowego. Zgodnie $\mathrm{z}$ rozporządzeniem MEN kwalifikacje do nauczania w liceach ogólnokształcących mają osoby, które ukończyły studia drugiego stopnia lub jednolite studia magisterskie na kierunk (spejalosci) zgodnejz nana kierunku (specjalności)zgodnejz nauczanym predichowadzonych zajęc oraz posiadają przygotowanie pedagogiczne ${ }^{2}$. Przez przygotowanie pedagogiczne, w ujęciu MEN, rozumie się nabycie wiedzy i umiejętności z zakresu pedagogiki, psychologii i dydaktyki szczegółowej, nauczanych w liczbie nie mniejszej niż 270 godzin w powiązaniu z kierunkiem kształcenia oraz odbytą praktykę

\section{oceniania, klasyffikowania i promowania uczniów} istuchaczy oraz przeprowadzania egzaminów i sprawdzianow w szkotach publicznych oraz Rozporzadzenie Ministra Edukacji Narodowej zania 2 l lutego 2000 r. przeprowadzania sprawdzinówi iegzaminów, Dziennik Ustaw z 2000 r. nr 17, poz. 215 .

Rozporzadzenie Ministra Edukacii Narodowej z dnia 1 sierpnia 2017 r. w sprawie szczegótowych kwalifikacii, wymaganych od nauczycieli, Dziennik Ustaw Rzeczypo-
spolitej Polskiej z 2017 r. poz 1575, \$3, ust. 1., pkt. . rych standardy wyznaczają rozporządzeni pedagogiczną w wymiarze nie mniejszym niż 150 godzin³.

Z kolei Rozporządzenie Ministra

Kultury i Dziedzictwa Narodowego formułuje wymagania, aby w szkołach plastycznych przedmiotów artystycznych (a historia sztuki w rzeczonych szkołach jest przedmiotem artystycznym) nauczały osoprzedmiotem artystycznym) nauczaly osow, ktore ukoh́czyły studia magisterskie wuczelni artystycznej lub w uczelni innej niż artystyczna na kierunku lub specjalności zgodnym z nauczanym przedmiotem lub rodzajem prowadzonych zajęć i posiadaja kwalifikacje pedagogiczne ${ }^{4}$. Co do kwalifikacji pedagogicznych w stosunku do nauczycieli MKiDN formułuje takie same wymagania jak MENs.

Zatem historii sztuki uczyć może tylko historyk sztuki, mający kwalifikacje pedagogiczne, na które m.in. składa się ukończenie kursu dydaktyki historii sztuki. Tymczasem na żadnej uczelni w Polsce - do 2001 r. - nie prowadzono dydaktyki tego przedmiotu. Szkoły artystyczne zatem przyjmowaly kandydatów na nauczyciel przyjma po kursie organizowa ASP w Poznaniu, poźniej przez Centrum Edukacji Nauczycieli Szkoł Artystycznych, a obecnie przez Centrum Edukacji Artystycznej, w którego programie znajdowała się m.in. dydaktyka tego przedmiotu. Dla nauczycieli szkół ogólnokształcących nie było propozycji.

Stworzenie na UKSW możliwości uzyskania kwalifikacji pedagogicznych dla studentów historii sztuki sprawiło, że $w$ wielu szkołach plastycznych i ogólnokształcących w całej Polsce historii sztuki

3 Tamże, § 2, punkt 2.

4 Rozporzadzenie Ministra Kultury i Dziedzictwa 政 szczegotowych kwalifikacji wymaganych od nauczyciel go i placówek doskonalenia nauczycielen, Dziennik Usta . 784 , 4 . Ust. 1.

5 Tamże, § 2. pkt. 2. uczą absolwenci Instytutu Historii Sztuki UKSW.

\section{ORGANIZACJA KURSU}

\section{KWALIFIKACYJNEGO}

PEDAGOGICZNEGO DLA

STUDENTÓW HISTORII SZTUK

UKSW

Historia sztuki nie jest jedynym kierunkiem, w którego programie kształcenia uwzględniono zdobywanie kwalifikacji pedagogicznych. Dlatego stworzona została odrębna jednostka - Studium Pedagogizacji ${ }^{6}$, która zajmuje się organizacją i koordynacją zdobywania kwalifikacji pedagogicznych przez studentów różnych kierunków.

Studenci, uczący się na kierunkach, które mają dydaktyki szczegółowe lub metodyki przedmiotu wpisane w program kształcenia (jako element przygotowania zawodowego), zdobywają kwalifikacje pedagogiczne bezpłatnie. Tak właśnie jest w przypadku historii sztuki. Zatem studenci tego kierunku składają wnioski do Studium Pedagogizacji o przyjęcie na kurs kwalifikacyjny. Poprzez Studium Pedagogizacji realizują też przedmioty pedagogiczne i psychologiczne (niektóre bezpośrednio w Studium, inne na różnych wydziałach uczelni). Pozostałe przedmioty (dydaktyka ogólna, dydaktyki lub metodyki szczegółowe) organizowane są bezpośrednio na macierzystych wydziałach.

$$
\text { W zajęciach dydaktyki ogólnej }
$$
uczestniczą na Wydziale Nauk

Historycznych UKSW studenci kilku kierunków, wśród których dominują studenci historii i historii sztuki (w obydwóch przypadkach przedmiot ten wpisany jest do programu kształcenia). W program kształcenia historii sztuki na studiach pierwszego stopnia jest też wpisana metodyka nauczania historii sztuki, która przygotowuje do 6 https://uksw.edu.pl/pl//informacje-biezace [dostęp 16 I 
1. Studenci III roku historii sztuki UKSW trakcie kursu pedagogicznego prowadzonego przez dr Beatę Lewińską, marzec 2019 r. N pierwszym planie Jagoda Florczykiewicz. Fot. T. Watanabe

nauczania na II etapie kształcenia szkolnego, czyli w klasach IV-VIII szkoły podstawowej. Aby jednak zdobyć pełne kwalifikacje uprawniające do nauczania także w liceach, technikach i szkołach plastycznych, należy odbyć zajęcia z dydaktyki ogólnej i metodyk szczegółowych nauczania historii sztuki na studiach drugiego stopnia.

\section{PROGRAM KSZTALCENIA}

DYDAKTYKI OGÓLNEJ I METODYK

NAUCZANIA HISTORII SZTUKI

Na zajęciach dydaktyki oǵlnej reatizowane są nastęujące zagadnienia: analiza aktów prawnych regulujących prace placowek edukayjy, funcjon a ie placomiotów: miotów: historia sztuki, historia, wiedza o społeczeństwie oraz historia i społeczeństwo w świetle przepisów prawa oświatowego, analiza i klasyfikacja metod i technik kształcenia ze szczególnym naciskiem na metody aktywizujące w nauczaniu.

Omawia się również najbardziej skuteczn metody wprowadzania nowego materia w nauczaniu historii sztuki i historii, w tym: wykład, wykład z prezentacją multimedialną, rozmowa nauczająca (dialog sokratejski), dyskusja, praca z tekstem źródłowym, praca z podręcznikiem, nauczan z wykorzystaniem technik multimedialnych, drama. Na zajęciach dydaktyki ogólnej omawiane jest też znaczenie w nauczaniu filmów i projektów edukacyjnych oraz gier i zabaw dydaktycznych, zwhaszcza w pracy zucznim modszym. Kilka godz w pracy z ucznien modszym. kilka godz zajęc poświęca się również ocenianiu zewnętrznemu (egzamin na zakończenie szkoły podstawowej oraz egzamin maturalny), procedurom organizowania egzam nów zewnętrznych, metodom kontroli i oceny oraz ocenianiu kształtującemu.

Zajęcia z metodyki nauczania histori sztuki na studiach pierwszego stopnia maja przede wszystkim przygotować studentów do nauczania w szkołach podstawowych.
Historia sztuki w szkołach podstawowych nauczana jest tylko jako innowacja pedagogiczna (dotyczy to zazwyczaj szkół niepublicznych, które staraj się poszer ed zowany jest pred zowany jest przedmiot plastyka, ktory zawiera treści teoretyczne z zakresu języka formy dzieła sztuki w powiązaniu z historią sztuki. Na ćwiczeniach tych analizowane są zatem podstawa programowa przedmiotu plastyka pod kątem treści

kształcenia, a także treści dopuszczonych do użytku szkolnego podręczników oraz przykładowych programów Studeniwoparcinopoznar studenci woparclu o poznane metody kształcenia uczą się przygotowywać sce riusze zajęć oraz pomoce dydaktyczne (w tym prezentacje multimedialne), a następnie przeprowadzają według jednego z napisanych przez siebie scenariuszy lekcję. Poznają też zasady formułowania wymagań edukacyjnych i przygotowują wymagania na wybrany rok nauki.

$$
\text { Zajęcia z metodyki nauczania historii }
$$

sztuki realiz stopnia przygow uią do podjęcia pracy w liceach, technikach i szkotach placty nych. W pierwsym roku nask plastezwykonuą zod ne wymaganiani pods wy progragowe z wymaganiami podstawy programowej ćwiczenia z zakresu opis i analizy dzieła architektury i sztuk plastycznych, opracowują wymagania edukacyjne na III etap kształcenia, przygotowuja scenariusze lekcji historii sztuki dla szkół ponadpodstawowych, opracowuja pomoce pondactaw w w pomoce didaktyczne, w tym prezentacje multimedialne i prze

W drugim roku nauki studiów drugiego stopnia studenci poznają zasady pomiaru dydaktycznego, uczą się formułowa przedmiotowy system oceniania z historii sztuki w powiązaniu z wewnątrzszkolnymi zasadami oceniania, wykonują ćwiczenia z praktycznego sprawdzania testów, ucza się budować kryteria dłuższej wypowiedzi

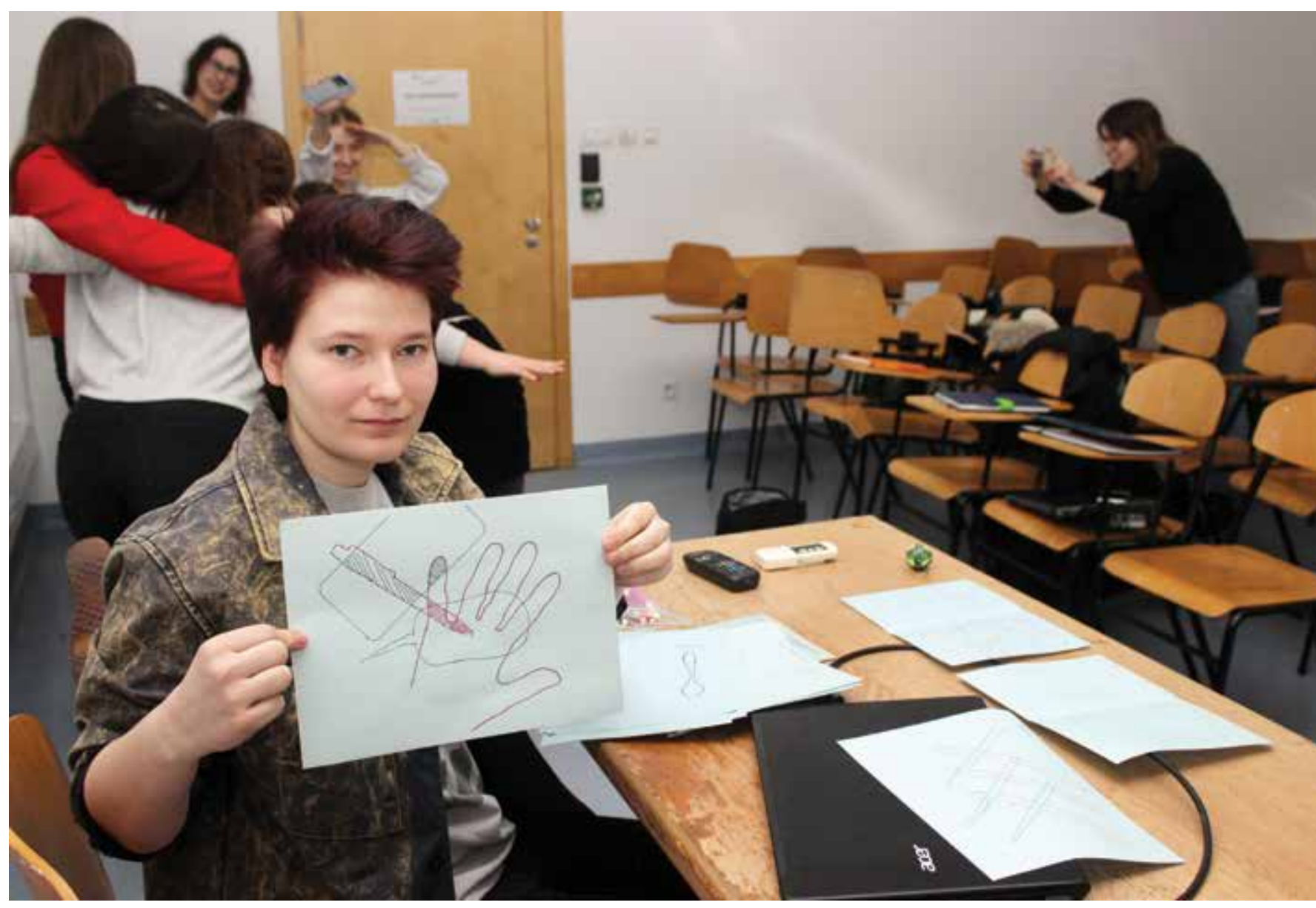

pisemnej, formułują kryteria oceny analizy dzieła sztuki. W toku nauczania poznają tez różne taksonomie celów ksztalcenia i uczą się konstruować testy pomiarowe oraz inne formy oceny poziomu osiągnięć (plan testu, kartoteka efektów kształcenia, test, model odpowiedzi i kryteria oceny). Ostatni semestr poświęcony jest konstrukcji i ewaluacji programu kształcenia przedmiotu historia sztuki. Ćwiczenia poświęcone są zatem analizie wybranych programów oraz konstrukcji programu autorskiego ze szczególnym uwzolędnieniem wyboru zanonu góny unz dzie z his indywidualnych potrzeb i możliwości uczniów, formułowaniu treści kształcenia.

METODY PROWADZENIA ZAJĘĆ

Z DYDAKTYKI OGÓLNEJ

Jak już wspomniano, jednym z najważniejszych modułów dydaktyki histori sztuki jest metodyka nauczania, czyli analiza metod kształcenia i wybór najbardziej skutecznych z nich w nauczaniu przedmiotu. Nie można jednak prz wać studenta do efektywnego nauczania hie są a rakcyjhe iskuteczne Jest to szczeǵ́ gónie istotne w przypadku dydaktyki metodyki nauczania historii sztuki, gdyż z praktyką. Dla przekazania treści z zakresu teorii nauczania należało zatem znaleźć taką forme, która uzmysłowi słuchaczom, jak ważny jest dobór odpowiednich metod, aby osiągnąc jak najlepsze efekty kształcenia.

Na wszystkich poziomach kształcenia wykładowcy, zwłaszcza początkujący zazwyczaj skupiają się na treści przekazu, powtarzając modele, zgodnie z którymi sami byli kształceni. Dwie formy kształcenia dominujące na kierunkach humanistycznych to wykład i ćwiczenia. Wykład jest nie tylko formą kształcenia, ale w przedmiotach tych łączy się teorię 
2. Studenci III roku historii sztuki UKSW w trakcie kursu pedagogicznego prowadzonego przez dr Beatę Lewińska, marzec 2019. Przy oknem dr Beata Lewińska. Fot. B. Kowalczyk

również metodą czy też modelem. Jako metoda cechuje się jedną podstawową zaletą, której nie ma żadna inna z metod: w krótkim czasie można przekazać relatywnie dużo informacji. Jest to jednak metoda bierduzo inform na z punktu widzenia słuchaczy. Na żadnym etapie wykładu nie można ocenić, na ile jest on skuteczny, ponieważ jedyną informacją zwrotną jest poziom skupienia słuchaczy. Jest to zatem metoda bardzo

trudna, gdyż wymaga nie tylko rzetelnego przygotowania treści, ale także nadania im atrakcyinej formy i wzięcia na siebie niem całej odpowiedzic całej odpowiedzial wasciza efekty. Jesli wykład nie speniswojego za dania, to znacz ze popelniony zostal bąd w realizacji. Wykład ma przy tym dużo ograniczeń. Jes metodą, która odbiera studiowaniu samodzielność. Krzysztof Kruszewski w swoje publikacji Kształcenie w szkole wyższej, powołując się na badania Włodzimierza Szewczuka podaje, że po zakończeniu wykładu $64 \%$ studentów recypuje jedynie od 1-33\% wykładu, 27\% studentów 34-67\% wykh wy a tylko $9 \%$ studentów - więce niz 67\%. $67 \%$. Badania szych latach po wojnie. W ostatnim czasie nastąpiło jednak ponowne zainteresowanie efektami kształcenia akademickiego, czego przykładem jest publikacja Kazimierza Denka Uniwersytet w perspektywie społeczeństwa wiedzy. Dydaktyka akademicka i jej efekty ${ }^{8}$.

Istnieją jednak pewne możliwości uatrakcyjnienia formy przekazu, jeśli wykladowca dazy do ukierz kowania na treści wykładu percepcji studentów i udaje mu się utrzymac ten kierunek procesu postrzegania przez cały czas trwania wykładu. Musi przy tym w taki sposób manipulowa zakresem bodźców, aby uniknąć znudzenia 7 K. Kruszewski, Kształcenie w szkole wyższej, Warszawa
1988, s. 14.

$8 \mathrm{~K}$. Denek, Uniwersytet w perspektywie spofeczeństwa

a i jej efekty, Poznań 201

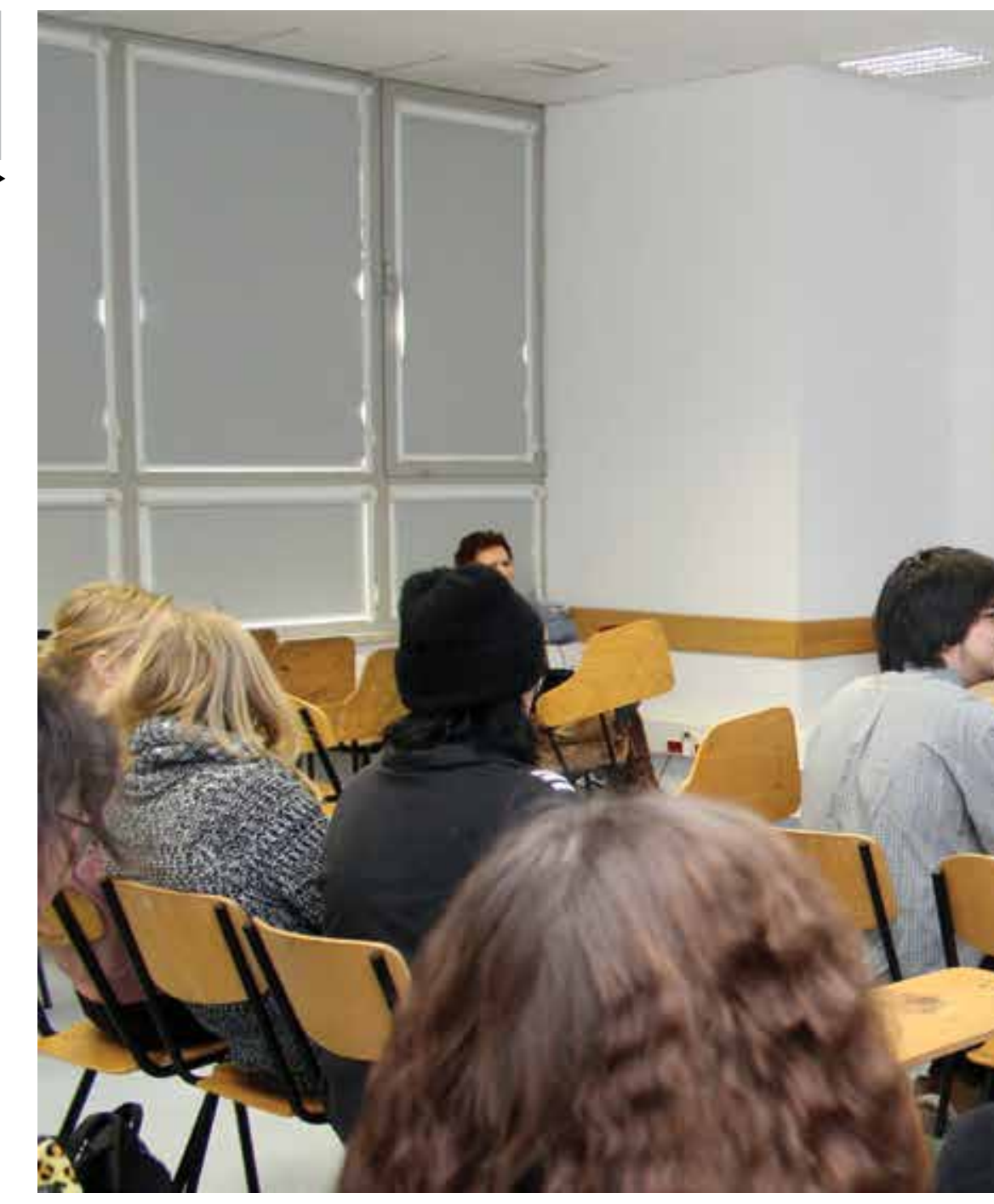

słuchaczy. To zagadnienie jest przedmiotem indywidualnych praktyk wykładowców, wspartych rozważaniami teoretycznym Rzadziej jest to opisywane w poradnikach dla wykładowców uniwersyteckich, ale często i w dużym zakresie w poradnikach dla szkoleniowców i nauczycieli. Warto tutaj powotać się chociażby na podręcznik Geoffa Petty'ego Nowoczesne nauczanie', czy też Richarda Arend

Przygotowujacc trociwykta nawąą stanawiąç się nad ich formą, należy wziąc pod uwagę fakt, że we współczesnym świe cie zmieniły się mechanizmy percepcji.

9 G. Petty, Nowoczesne nauczanie. Praktyczne wskazówki i techniki dla nauczycieli, wykładowców iszkoleniowców, thum. J. Bartosik, Sopot 2013 10 R. Arends, Uczymy się nauczać, tuum. K. Kruszewski, W pokoleniu obecnych pięćdziesięciolat dominują ludzie obdarzeni pamięcią słuchową. Łatwo ich poznać, poniewaz chaszym stopniu potrzebują szczegółowych notatek od ludzi, których cechuje pamięć wzrokowa Studenci słuchowcy" uczą się wzrokowa. Studenci „słuchowcy" uczą się poprzez powtarzanie na głos. Lubią uczyć się w gronie kolegów, bowiem poprzez we balizację problemu następuje proces restrukturyzacji wiedzy. Kultura współczesnego świata to przede wszystkim „kultura obrazkowa”, co jest powszechnie wiadome. Dlatego pokolenie obecnych studentów, epatowane obrazami, wykształca przede wszystkim pamięć wzrokową a „wzrokowcy" potrzebują bodźców wizualnych. W odróżnieniu od studentów obdarzonych pamięcią słuchową konstruują znacznie bardziej szczegółowe notatki, a kiedy się uczą, wystarczy im czasami spojrzenie na stronę zapisanych notatek, żeby przypomnieć sobie ich treść. Niestety, prowadząc szczegółowe notatki koncentrują się często nadmiernie na analizowaniu treści wykładu, w związku z tym nie zawsze potrafią swoje notatki odpowiednio ukształtować i wychwycić rzeczy nadrzędne nad treściami ilustrującymi problem. Ponadto trzeba zauważyć, że zmienił się i stale się zmienia profil studenta. Niż demograficzny, powszechność kształcenia wyższego i zmiana polityki panstwa w tym zakresie wpłynęły na fakt, że na uczelniach wyższych pojawili się także studenci, którzy nie reprezentują ani szczeoólnego wykształcenia, ani wysokiego ilorazu inteligencji. Nie zmienia to faktu, że nauczanie 
musi wiązać się z jakością. Dlatego bardzo ważne jest, żeby dobrać i dostosować odpowiednie metody do każdeoo ze słuchaczy. Ponieważ wónód studentów (zwaszcza historii sztuki) przeważają osoby o dominacji pamięci wzrokowej, trzeba wykład tak prowadzić, aby wyjść naprzeciw ich oczeki
niom i możliwościom percepcyjnym.

m i możliwościom percepcyjnym.
Na zajęciach dydaktyki ogólnej, prowadzonych w formie wykładu, uwzględniono zatem następujące czynniki.

Wszystkie najważniejsze treści wykładu ujęte zostały w syntetyczny konspekt, który jest zwizualizowany w trakcie zajeć. Jeżliwykladwymagat ilustraji, laczon Jeżeli wyklad wymag i laczono tekst z obrazen. Doswiadczeniepokazało, że osiąga się znacznie wyższy poziom skupienia słuchaczy, jeśli prezentowany obraz ma opisaną metryczkę. Studenci zamiast rozpraszać się, poszukując w cudzych notatkach lub w mediach sposobu zapisu (np. nazwiska autora lub pojęcia o obcej genezie), przepisywali go poprawnie z prezentowanego tekstu.

Ponadto zajęci notowaniem szczegółów studenci nie potrafią uchwycić logicznego i merytorycznego porządku wykładu. Wizualizacja jest zatem bardzo istotną sprawą, ponieważ odwołuje się bezpośrednio do pamięci wzrokowej studentów. Przeprowadzana corocznie ewaluacja zajęć z dydaktyki i metodyki nauczania historii sztuki w postaci wywiadów typu focus pokazała, że taka forma prowadzenia bardzo odpowiada słuchaczom. Z drugiej strony nie można jednak preferować osób z przewaga pamięci wzrokowej nad słuchową. Dlatego do każdego pokazywanego obrazu należało zrobić długi wywód w postaci komentarza, korzystając z zaleceń, jakie sformułowane są w poradnikach dla szkoleniowców, aby nie powtarzać treści pokazanych na slajdzie, lecz uzupełniać i poszerzać je, bądź tylko parafrazować zapis.

Kolejnym sposobem na uatrakcyjnienie wykładu była zmiana jego formuły z konwencjonalnej, informacyjnej na wykład konwersatoryjny. Wykład taki poła czony był z aktywnością samych słuchaczy, kierowana na rozwiązywanie problemów choblemów wo wykład z dydaktyki można było odwoływac się nie tyle do wiedzy słuchaczy, ile przede wszystkim do ich doświadczenia. Oczywiście sprzyja temu tematyka, która dotyczy metod kształcenia w szkole. Bardzo ważny był też stosunek emocjonalny słuchacza do treści wykładu, bowiem w ten sposób polepszała się jego recepcja. Odwołanie do własnych doświadczeń sprawiło, że zmienił się model kształcenia w kierunku modelu waloryzacyjnego, czyli angażującego nie tylko myśli, ale także uczucia. Przy czym, jak zauważył Arends, uczucia. Przy czym, jak zauważył Aren W wielokrotnie wznawianej puby Zjednoczonych doczekała się ona sześciu wydań, a w Polsce jednego - w tłumaczeniu Krzysztofa Kruszewskiego), bardzo duże znaczenie dla atrakcyjności wykładu ma stopień entuzjazmu prowadzącego.

Charakteryzują go określone zachowania: modulowana dykcja, harmonia ruchu, zróżnicowane i wyrażające emocje sposoby poruszania się, częste formułowanie pytań Duże znaczenie ma wartkie tempo, ale znacznie większe - wplatane w tok wykładu dygresje, które nieco odchodzą od zasadniczych treści, ale interesują słuchaczy. Dygresje podczas wykładu z zakresu meto kształcenia wiązały się z tematyką wistotny sposób, gdyż moź ny sposób, gdyż mozna zię było odwołać do Recen pedagogicz

Recepcja wykładu jest znacznie wyż sza, jeżeli wykładowca nawiązuje kontakt wzrokowy ze studentami, a nie jest to możliwe, jeżeli kontroluje tok wpatrując sie w notatki. Dlatego zrezygnowano z notatek lub zminimalizowano potrzebę posługiwania się nimi. Do rozwinięcia wystarczył

$\overline{11 \text { Tamże, s. 270-271. }}$ wizualizowany konspekt (który widzą równocześnie studenci). Wykładowca mógł wówczas kontrolować uwage słuchacz a ci mieli szansę na stworzenie dobrych, odpowiednio ustrukturyzowanych notatek, które wspomagają rozwój myślenia yntetycznego.

Z badań wynika, że recepcja wykład nie jest wartością stałą. Uwaga słuchacz rośnie i spada w poszczególnych sekwencjach, które zobrazować można na podobienstwo sinusoidy ${ }^{12}$. Zazwyczaj uwaga słuchaczy rośnie i spada w około 2o-minutowych sekwencjach. Ważne jest zatem, żeby wycelkwe korzystywaćnasion nie tresci trudniejsych, kố ny wagają zrozumienia izapamiętania. Wokresie spadku uwagi wplatane zatem są dygresje lub parafrazując powtarza się treści trudniejsze. Wykład musi być stymulujący, powinien dopingować studentów do własnyc przemyśleń, stwarzać okazję do formułowania własnego zdania na temat niektórych problemów Kiedy w trakcie wykładu pojawialy się opinie studentów na temat

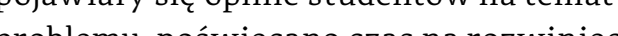
problemu, poswięcano czas na rozwinięcie tematu. Tok myslenia studentów był šledzony, a treści modyfikowane do ich potrzeb. Taka forma przekazu okazała się najbardziej atrakcyjna dla studentów.

\section{CWICZENIA Z METODYK}

DUCZANIA HISTORII SZTUKI DaUCzANIA HISTORII SzTuKI dzenia zaję́ na ucze ni to ćwiczenia. Z z kresu metodyki nauczania historii sztuk jest to go godzin na studiach pierwszego stopnia i 120 godzin na studiach drugiego stopnia. W modelu kształcenia akademickiego, nie tylko z zakresu historii sztuki, ale w ogóle kierunków humanistycznych, dominują formy realizacji ćwiczeń w postaci referatów studenckich. W praktyce oznacza to, że dla większości słuchaczy jest to

12 K. Kruszewski, dz. cyt., s. 18 też wykład, ale prowadzony przez osobę mniej doświadczoną i słabiej przygotowaną merytorycznie. To sprawia że stałych słuchaczy drastycznie spada, zwłaszcza jeśli jakość referatu zmusza prowadzącego do korygowania treści w trakcie czytania. Słuchacze w takich przypadkach tracą zaufanie do rzetelności przekazu i nie są zainteresowani sporządzaniem notatek. W przypadku dydaktyki historii sztuki referaty były bardzo słabym modelem, gdyż doświadczenie studentów w tym zakresie jest tak niewielkie, a publikacje tak różnorodne, że nie sprzyjało to osiągnięciu właściwych efektów kształcenia.

Alternatywnym sposobem, który został wypracowany w wyniku refleksji nad prowadzonymi zajęciami i w wyniku obserwacji wspomnianych efektów kształcenia, stało się prowadzenie ćwiczeń zadaniowo. W przypadku metodyki nauczania historii sztuki zdecydowanie sprzyja takiemu podejściu fakt, że studenci przede

wszystkim muszą wykształcić umiejętności prawidłowego konstruowania nązędzi dydaktycznych niezbędnych w szkole: scenariuszy zajęć, wymagań edukacyjnych, programów kształcenia, które wspomniano powyżej.

Model kształcenia zadaniowego połączony został zatem z metodą stolików eksperckich (nazwa ta funkcjonuje powszechnie w kształceniu akademickim, natomiast podobna metoda stosowana w kształceniu uczniów szkół średnich funkcjonuje pod nazwą „uczenie się we współpracy"). Ten model kształcenia jest szczególnie pożądany, bowiem nie tylko wyposaża studentów w niezbędną wiedzę i umiejętności, ale przede wszystkim wychowuje do współpracy, co jest nawykiem bardzo istotnym na rynku pracy.

Pożądanym na rynku kandydatem nie jest dziś osoba nastawiona na sukcesy indywidualne, lecz zdolna do pracy zespołowej, która jest obecnie najczęstszą formą 
wykonywania zadań. Ważne jest w związku z tym takie kształcenie, które uwzględnia również określone kompetencje społeczne. Uczenie się w tym modelu polega na aranżowaniu sytuacji umożliwiających studentom osiaganie celów (nauczenie) $\mathrm{z}$ jednoczesnym ograniczeniem rywalizacji. Bardziej jest to zatem idea niż metoda. Sprawia też, że inne zastosowane przez wykładowcę metody przynoszą lepsze efekty. Nie możn bowiem zapominać, że uczenie się jest procesem społecznym, zachodzącym dzięki relacjom z innymi ludźmi. Istnieje ogromna potrzeba stosowania metod ksztalcenia, pymajacych od studentow werbalizow wymagających od stuentow werballzow nia myśli i komunikowania się. Tego rodzaju sytuacje uczą demokracji, a zwłaszcza dzielenia się opiniami, słuchania innych, pełnienia ról, podejmowania decyzji, rozwiązywania konfliktów, ustalania norm grupowych, efektywnej pracy nad zadaniem, podziału zadań, a wreszcie odpowiedzialności za realizację. Studenci wybitni zyskują możliwość doskonalenia wiedzy ponieważ najczęściej w pracy zespolowe poniewaz najczęsciejw pracy zespolowej przejnują wnaturalny sposób rolęliderów grupy, a uczenie innych wymaga dokładne go zrozumienia zagadnienia, przemyślenia zilustrowania przykładami, uproszczenia i przekształcenia.

Z uwagi na zmieniający się coraz bardziej profil studenta, o czym już było powyżej, nie można też zapominać, że mamy tutaj wartość dodaną w postaci faktu, że studenci przeciętni i o słabszym potencjale taj war intelektualnym we zyskują środowisko dające im poczucie bezpieczeństwa i motywujące do wysiłku (czego nie doświadczają, kiedy realizują ćwiczenia w postaci indywidualnych referatów). Zajęcia realizowane w takim modelu w znaczący sposób podnoszą ich samoocene

tudentom bardzo odpowiada taki posób kształcenia, w którym pracują nad zadaniem w grupach. Na ćwiczeniach z dydaktyki historii sztuki są to grupy niewielkie - zazwyczaj dwu- lub trzyosobowe. Przy czym tworzą sie bardzo pozytywne relacje w grupie, wpływające na efektywnóć pracy. Poniewaź pracują nad zadanianośc pracy Poniewaź pracują nad zadaniaceduralne bądź strukturalne, rolą nauczyciela jest nieustanne korygowanie uzyskanych efektów i naprowadzanie na właściwe rozwiązania. Decydując się na wspomniany model kształcenia ma więcej czasu na obserwację pracy studentów, a studenci zmieniają treść rozmów w czasi zajeć w kierunku pożądanym. Są różne for-

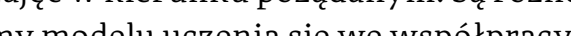
my modelu uczenia się we wspolpracy, . w'. Jedna z nich to metoda badan zespołowych (praca grupy nad wspólnym zadaniem, w którym okazję do współpracy stwarza fakt, iż studenci mają się wymieniać doświadczeniami i udzielać wyjaśnień). Metoda wymaga wyrafinowanych struktur dydaktycznych. Studenci wybierają zakres, organizują się sami w zespoly adaniowe, wspólnie planuą cele, zadania procedury, realizują je, dokonują analizy syntezy pracy, a wreszcie przedstawiaj opracowanie końcowe. Drugim ze sposobów jest metoda tzw. składanki. W każdym zespole macierzystym funkcjonują studenci odpowiedzialni za swoją częśc zadania. W ten sposób stają się oni ekspertami tej części i wspólnie z ekspertami z innych grup mogą ustalać rozwiązania i uzgadniać swoje stanowisko w poszukiwaniu wháciwych rozwiązan. Tworzą zatem podgrupy, zwane „eksperckimi . Na koniec powra do swoich zespołow macierzystych, a wszystkie części ich pracy połączone raem składają się na „produkt” końcowy catej grupy

Obydwa opisane przypadki były praktykowane na zajęciach metodyki nauczania historii sztuki i okazały się

3. Arends, dz cyt. s.346-350. najskuteczniejszą metodą praktycznego przygotowania do pracy nauczyciela. Oczywiście częśc zadań wykonywana byla też przez studentów indywidualnie.

W roku akademickim 2013/14 po raz pierwszy w tok ćwiczeń z metodyki nauczania historii sztuki włączona została metoda e-learningu, ale w taki sposób, żeb nie zastępowała ona tradycyjnych spotkan lecz uzupełniała je. Niektóre etapy pracy nad zadaniem studenci mogą bowiem wykonywać samodzielnie pod warunkiem, że przygotowane zostaną dla nich odpowiednie wzorce, przykłady i narzędzia.

Spotkania służą z jednej strony weryfikacji

Spotkania suż z jed in strony weryfik

ich dotychczasowej pracy, a z drugiej są przygotowaniem do następnych etapów. ziła się w toku zajęć.

OPIS I ANALIZA DZIELA SZTUKI

Osobnym problemem w przygotoształcenie umiejętności opisu riela sztukiv wymaszest przedmiotu, zarowno tych, ktore obow (jack będą od 1 września 2019 r. ${ }^{14}$ Wymaganie to

4 Obecnie realizowane są dwie podstawy programowe przedmiotu historia sztuki: w liceach ogónokształ Ministra Edukacij Narodowej z dnia 23 grudnia 2008 w sprawie podstawy programowej wychowania przedszkolnego oraz kształcenia ogólnego w poszczególnych typach szkót, Dziennik Ustaw z 2009 r., nr 4, poz. 17 z pozzniejszymi zmianami w Rozporzadzeniu Dziennik Ustaw z $2012 \mathrm{r}$ poz 977 , natomiast

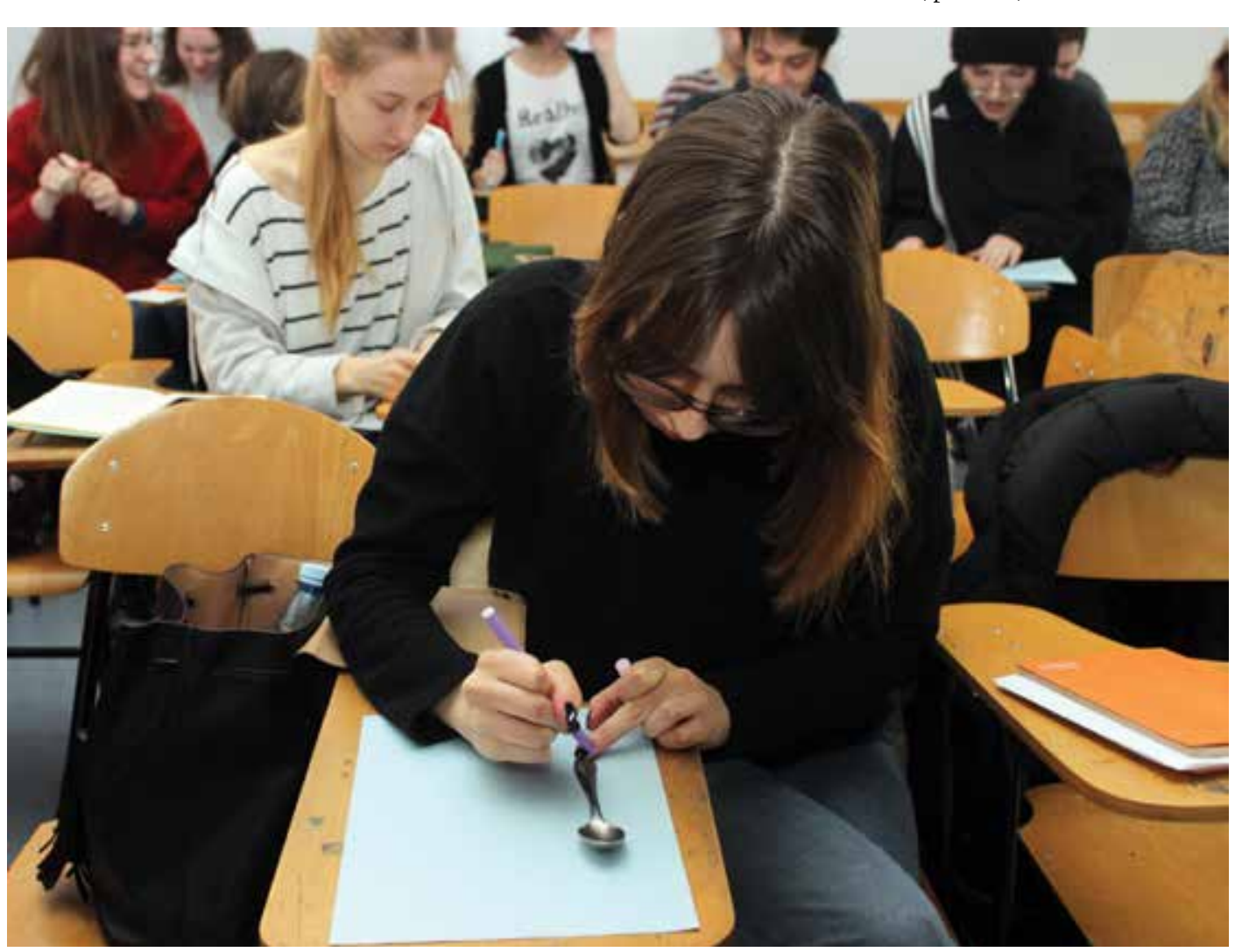

3. Studenci III roku historii sztuki UKSW w trakcie kursu pedagogicznego

prowadzonego przez dr Beatę Lewińską, marzec 2019 r. Na pierwszym plani

kowalczyk, Fot. T. Watanabe 
jest sprawdzane na egzaminie maturalnym.

Wiedza z historii sztuki jest tylko częścią wymagań zawartych w podstawach programowych. Tworzenie wypowiedzi na temat sztuki oraz analiza i interpretacja dzieł sztuki i tekstów kultury są umiejętnościami kluczowymi w nauczaniu histori sztuki. Uczeń musi porównywać style i kierunki i ich wzajemne oddziaływania, uwzględniać źródła inspiracji, brać pod uwagę różne konteksty powstawania dzieła, jak wpływ mecenatu artystycznego, wydarzeń historycznych i kulturalnych, religii i estetyki na cechy tych stylów.

Ponito powinien for tych stylow. Ponadto powinien for ne wypowiedzina temat sztuki, poddawa krytycznej ocenie artystycznej dzieła i zjawiska w sztuce, a ponadto dokonywać opis i analizy porównawczej dzieł, uwzględniając ich cechy formalne. Powinien także analizować teksty pisarzy, filozofów i artystów, interpretując je i wskazując wpływ tych wypowiedzi na charakter stylów, epok tych wypowiedzi na charakter stylow, ep a w publika wach z zakresu histori dzieła, a w publikacjach zzakresu historilsztuki pretacji i analizy. Osiąganie tych efektów

w ogólnokształcących szkołach sztuk pięknych liceach plastycznych podstawa opublikowana Wrodowego 15 grudni 2016 r.w programowych kształcenia w zawodach szkolnictwa artystycznego w publicznych szkołach artystycznych, Dziennik Ustaw z 2016 r., poz. 2248. W klasach pierwszych liceuni pullkowa w Rozprzedzeniu Ministraduhaci Narodowej z dnia 30 styczzia $2018 \mathrm{r}$. w w sprawie podstawy programowej kształcenia ogólnego dla liceu ogólnokształcacego, technikum oraz branżowej szkoły II stopnia, Dziennik Ustaw z 2018 r., poz. 467, natomiast w klasach pierwszych liceów sztul opublikowana w Rozporzadzeniu Ministra Kultury Dziedzictwa Narodowego z 6 września 2017 r. w sprawie podstaw programowych kształcenia w zawodach szkolnictwa artystycznego w publicznych szkoła
artystycznych, Dziennik Ustaw z 2017 r., poz. 1793. wymaga od nauczyciela mądrej i świadomej metodyki pracy z uczniem, zatem w tym szli nauczyciele historii sztuki.

Kształtowanie umiejętności opisu analizy dzieła w zakresie wspomnianych wymagań podstaw programowych również najpełniej sprawdza się w pracy grupowej. Studenci sami muszą ćwiczyć opisy i analizy, a znacznie łatwiej im przychodzi to we współpracy, ponieważ uzupełniają się nawzajem i korygują swoje spostrzeżenia w przyjaznej i bezpiecznej atmosferze, uruchamiajac model kształcenia powszechnie

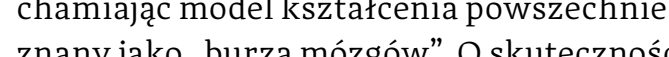
znanyjako „buza mozgów". O skuteczności wita swoboda wąu antaj wstępna całkowita swoboda wysuwania hipotez rozwiązywanego problemu. Dopiero na kolejnym etapie następuje ich weryfikacja z udziałem wszystkich studentów i prowadzącego. Ogromne znaczenie ma tutaj także efekt oceny koleżeńskiej wypracowanych rozwiązań i samooceny (krytyczne podejście samego studenta w kontekście osiągnięć innych członków grupy).

Jak zatem wynika z przedstawionych przykładów, najbardziej skutecznym sposobem prowadzenia ćwiczeń z metodyki nauczania historii sztuki jest model uczenia się we współpracy. Ze względu na fakt, że celem tych ćwiczeń jest wypracowanie i przygotowanie konkretnych narzędzi, łączy się to z modelem zwanym „metodą projektu", czyli realizacja przez studenta lub grupę studentów dużego zadonia praktycznego. Zadanien prowadzącego jest początkowo insirowanie do tworzenia, a następnie kontrolowanie jego przebiegu i ocena jego jakości. Taka praca, zwłaszcza nad formułowaniem programu nauczania ma charakter wieloetapowy.

\section{KONKLUZJE}

Wypracowane w praktyce wykładowcy dydaktyki historii sztuki metody i modele kształcenia nie są tak naprawdę niczym nowym w kształceniu akademickim, choć często zapomnianym. Sprawdzają się jednak w praktyce. Narzędzia dydaktyczne, które tworz

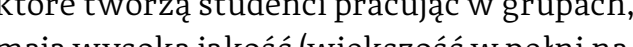
mają wyso ka jasc (wiekszośc w petninadaje się do publikacji w pismach branzzowych dla nauczycieli). W związu z tym skuteczność przygotowania ich do pracy zawodowe jest osiągana. Szczególną wartość stanowią pisane przez studentów programy nauczani historii sztuki. Zauważyć trzeba, że napisanie programu jest rzeczą trudną nawet dla nauczyciela. Niebagatelną rzeczą w osiaganiu celów jest też motywacja plynąca stąd, że studenci historii sz ze studenci historis ż w przeciwienstwie do nauczycieli innych przedmiotów ogólnokształcących nie będą mogli liczyć na gotowe narzędzia i pomoce zaproponowane przez wydawnictwa wraz z podręcznikami. Rynek odbiorców jest zby mały, żeby zainteresować firmy nastawion na osiąganie zysków przygotowywaniem materiałów dydaktycznych z zakresu historii sztuki.

Ponieważ treści dydaktyki ogólnej i metodyki nauczania historii sztuki,

zwłaszcza przekazywane i praktykowane podczas ćwiczeń, wiążą się z koniecznością podejmowania dyskusji na temat model i metod kształcenia, niewątpliwą wartościa dodaną są refleksje studentów na temat metodyki i formułowane przez nich opinie. Tak było w przypadku oceny wartości prezentowanych na zajęciach ilustracji.

Możliwości percepcyjne studentów są

Możliwosci perce

Prezentowanie bardzo dużej liczby slajdów z ilustracjami dzieł sztuki sprawia, że studenci, dążąc do zapamiętania, zwracają uwagę na czynniki niemerytoryczne. Poszukując dobrych modeli kształcenia, słuchacze biorący udział w zajęciach dydaktyki i metodyki historii sztuki sformułowali wniosek, dotyczący zasad kształcenia licealistów uczacych się historii sztuki. Najważniejszą zasadą jest wskazanie ilustracji, które są niezbędne do zapamiętania (np. oznaczenie ich odmiennym kolorem pisu), od ilustracji, które poszerzają zakres, egzemplifikują problem lub stanowia dowód postawionej tezy. Studenci, konstruując własne narzędzia dydaktyczne dla uczniów i zainteresowanych historią sztuk słuchaczy, tak właśnie czynią w swoich prezentacjach.

\section{TEACHING HISTORY OF AR \\ AT THE CARDINAL STEFAN \\ WYSZYŃSKI UNIVERSITY}

IN WARSAW - PRACTICE

\section{REFLECTIONS CONCERNING THE}

\section{METHODOLOGY OF EDUCATION}

\section{BEATA LEWIŃSKA}

Didactics of art history at the Institute of Art History at the University of Cardinal Stefan Wyszyński has been the subject of education since 2001. The need to introduce this type of classes was determined by the desire to include practical elements in the study program in the history of art, wich will open up new opportunities for the students in the labor market. The history art has been taught in art schools since the Second World War, and since 2005 it has been the subject of the secondary school certificate examination. In 2008, Ministry of Education introduced the history of art to secondary schools as an additional subject. Cardinal Stefan Wyszyński University was the first universty in Poland where didactics an dactics and nethodolygy for teaching art plementation of these classes along with pedagogical and psychological subjects, students of art history obtain pedagogical qualifications and take up work in schools. This article also introduces the teaching programs and methods of their conduct. 